Canadian Journal of Higher Education Revue canadienne d'enseignement supérieur

Volume 44, No. 2, 2014, pages $30-48$

\title{
Liberal arts catch-up revisited
}

John Goyder

University of Waterloo

\begin{abstract}
This paper replicates the work of Giles and Drewes from the 1990s.They showed a catch-up effect whereby graduates of liberal arts undergraduate programs, although at an early-career disadvantage compared with graduates of applied programs, had higher incomes by mid-career. Working with the Panel 5 Survey of Labour and Income Dynamics (2005-2010), the catchup no longer exists.
\end{abstract}

\section{Résumé}

Cet article reproduit le travail de Giles et Drewes effectué pendant les années 1990. Ces chercheurs avaient révélé un effet de rattrapage grâce auquel les diplômés de programmes d'études en arts libéraux, malgré un désavantage en début de carrière par rapport aux diplômés de programmes d'études appliquées, finissaient par avoir des revenus plus élevés vers le milieu de leurs carrières. Selon les données de l'échantillon 5 de l'Enquête sur la dynamique du travail et du revenu (2005-2010), ce rattrapage n'existe plus.

\section{Introduction}

Some of the most heartening news for those who believe in the value of a liberal arts education was a finding from the first panel (1993) of Statistics Canada's Survey of Labour and Income Dynamics (SLID). Using these data Giles and Drewes (2002) showed that, although liberal arts graduates encounter more difficulties than applied-field graduates do in entering the labour force at a level appropriate for the university educated and suffer more job transitions and spells of unemployment over the first half-dozen years, by midcareer a catch-up occurs. Their sample was divided into under age 25 (hence recent labour force entrants), 25 to 34 (early career), 35 to 44 (up to mid-career) and 45, and over (midcareer and beyond) and showed that income as computed as hourly-wage equivalent was 
a little higher by age 45 on for those with humanities and social sciences backgrounds than for applied program graduates. Although initially reported in the Statistics Canada house publications Perspectives on Labour and Income and Educational Quarterly Review, the Giles and Drewes finding received additional coverage in the Ontario Confederation of University Faculty Associations Forum (Drewes, 2002). The study was noticed within both academic research (Frank and Walters, 2012, p. 97) and in the popular media such as the Globe and Mail (September 24, 2001, p. B8). Echoes of this same catch-up pattern can be seen in the 1996 census data analyzed by Axelrod, Anisef, and Lin (2001, Tables 2 and 3), where field of study differences in employment success narrowed when comparison was limited to those aged 30 and over. Heisz (2001) found income convergence by 1997 for graduates of British Columbia universities tracked from convocations dating 1974 onward. Catch-up, sometimes referred to as "sleeper effect," is an important consideration within the subfield of research known as "horizontal stratification" (Gerber and Cheung, 2008; Torche, 2011, p. 768) in postsecondary education, one of the "two axes of stratification within higher education," noted by Davies and Guppy (1997, p. 1419).

Despite the encouraging finding for catch-up, the more dominant message in research and discussion on liberal arts education has been concern about under- and unemployment among humanities and social science graduates. This view has persisted through the 1990 and 2000 s up to the present day and has found expression within both academic literature (Coates and Morrison, 2011, p. 37-39; Côté and Allahar, 2007, 2011; Finnie, 2001, p. 117; Finnie and Frenette, 2003; Frenette, 2004; Livingstone, 1999; Walters, 2004a) and in the popular media such as The Globe and Mail (May 1, 2012, A13; August 30, 2012, B4). Several such discussions convey growing doubts about how well modern universities teach the basic liberal arts skills of communication and reasoning to undergraduates, an issue examined by Arum and Roska (2011). There is also a feeling that the economy needs more science-technology graduates and fewer from the humanities and social sciences (Coates and Morrison (2011, p. 207-20-9). Meanwhile catch-up was notably not mentioned in the important state-of-the-field review article by Gerber and Cheung (2008).

Different streams of research seem to be failing to inform each other on this topic. Perhaps those who comment on problems with higher education are neglecting to absorb the importance of research such as Giles and Drewes', due to a fixation with recent graduates and the neglect of the longer time frame. For example, if deans of arts or social science faculties are consistently hearing tales of struggle from their recent graduates, this may override a more encouraging message from Statistics Canada surveys of the full adult age range. Years ago R.B. Freeman $(1971,1976)$ showed that the labour market for recent university graduates is inherently unstable, with a constant attempt by the future to catch up with the past. Livingstone (2009, p. 312) argues that higher education and the labour market are "quite different systems" with "different objectives, functions, and time horizons." From both these viewpoints, the early-career statistics carry a lot of "noise" and are best de-emphasized, and the mid-career results, favourable to liberal arts graduates, are the more meaningful. Alternatively, however, the catch-up pattern Giles and Drewes found for the 1990 s may no longer exist. The confounding factor here, and investigated below, is the difficulty of the possible conflation of history and maturation that may occur when bringing survey data decisively to bear on the question of employment prospects for different types of university degrees. 


\section{Maturation-History Ambiguity}

The SLID analysis just noted was based on a maturation argument. The claim was not that the cohort of liberal arts graduates aged 45 plus in 1993 were out-earning counterparts with applied degrees at the time these workers first entered the labour market. Rather, the point was that with maturation, liberal arts skills become increasingly valuable. As Giles and Drewes (2002, p. 25) suggested, "the skills they [i.e., liberal arts graduates] acquired have a greater longevity and are complementary to continued, lifelong learning in the face of labour market changes." This should be a robust analysis over "history," given that every year has its own unique blend of business fluctuations, elections, changes in government economic policy or education policy, impacts of international events, and shifts in cultural values. Indeed, as the economy becomes ever more tumultuous, the fact that liberal arts skills are, as Giles and Drews noted, "more portable" should be a lasting and even growing advantage. Adamuti-Trache, Hawkey, Schutze, and Glickman (2006, p. 51), in their study on recent university graduates in $\mathrm{BC}$, echoed the case for the importance of a liberal arts education for workplace skills. There are many such affirmations in the literature.

In counterpoint to this image of the flexible-skilled liberal arts graduate, think of the applied program graduate with technical skills. Let's pick on computer programmers: swallowed up by Bill Gates or other computer moguls when they first graduated from their computer science program, now, fifteen years down the line, they can be replaced by 21-year-old graduates who, to deliberately caricature for effect, "know twice as much about modern programming and can be paid half the wage of the mid-career person." There is ample material in Livingstone (2009, Chapter 8) to challenge that stereotype, but a Weberian ideal type is being imagined here. The notion of vocational skill obsolescence does receive serious mention in the literature on work and education. As Axelrod, Anisef, and Lin (2001) noted in the CJHE: "Much technical knowledge, after all, has a limited life span." Walters (2004b, p. 4) expressed the views of several other researchers who think along the same lines: "In fact, in light of rapid technological change, the acquisition of specific technical skills may be risky."

The counter to this maturation account is the historical one, sensitive to the way that those aged 45 and up in 1993 were beneficiaries of the post-World War II economic boom. A 45-year-old in 1993 would have been born in 1948 and, in the linear path from school to postsecondary education to work, characteristic of that era, this person typically entered the labour force sometime around 1969-1970. In 1993 those at the retirement age of 65, mandatory for most occupations in those days, entered the work force around 1949-1950, possibly one of the choicest moments in history to begin working with a newly minted bachelor's degree in hand. The culture of science and technology was already there, soon to be reflected by Sputnik and the space race, even if it was not so dominant as it became with the microelectronic revolution symbolized by the mid-1970s beginnings of the personal computer. If the liberal arts were better respected prior to about 1975, no wonder such degree holders had made huge career strides by 1993, even if their university training lacked obvious practical applications. They were a small cohort dropped into an expanding industrial economy. It was, in this alternative interpretation, a one-time opportunity not to be enjoyed by the later generations. 
In the analysis reported herein, I seek to resolve the maturation-history ambiguity by examining the most recent SLID data. The objective is to determine if the liberal arts catch-up theme was still holding as Canada moved into the 2000s. Going to the more recent data admittedly is not a definitive affirmation of the value of liberal arts education, no matter how promising the findings might be, because it is still not known where 21-yearolds in, say, 2014 will be 25 years later in 2039 and beyond. If, however, the Giles and Drewes finding of catch-up in 1993 held in data from a half generation later (i.e., about 12 years, since my data are from the mid-200os), this would be valuable information. The argument in favour of the generic, portable skills that professors in the humanities and social sciences like to believe they give to their students would be enhanced.

\section{Procedures}

SLID is a longitudinal survey designed to give accurate estimates of income, occupation, and unemployment year-by-year. Respondents are tracked over six-year spans, a relatively short period for longitudinal purposes, but one that helps keep the problem of drop-out and attrition under control. Six years is a meaningful interlude from the viewpoint of a recent university graduate, typically in his or her twenties, about to enter the labour force. The SLID for any one-year cross-section is actually comprised of two subsamples, since half the sample enters every three years. Thus the original SLID dataset, first collected in 1993 and designated "Panel 1," has some 30,000 respondents from some 15,00o households. In 1996, Panel 2 with the same approximate numbers was added, and these fresh respondents remained under study until 2001 (whereas the Panel 1 people exited after 1998). See Statistics Canada (2005) for details on the survey design. Giles and Drewes examined Panel 1. I used Panel 5 for the comparison, the sample first contacted in 2005, terminating in 2010.

The earlier analysis selected those whose highest level of education was a bachelor's level degree as of January 1, 1993. Note that this analysis deliberately sets aside people who obtain a bachelor's in one of the liberal arts disciplines but then proceed to a higher degree, such as a Master's or Ph.D. in the same discipline, or a graduate program such as law, MBA, library science, or one of the proliferating new "professional masters" degree programs such as public administration or health studies. ${ }^{1}$ The question for the present is what are the career prospects for the person who completes a first degree and then proceeds to the workforce? Granted, today many would begin with that path, then some years later return to academe for further education in a non-university program. I examine these people later in the analysis, but begin as just described. Recall, too, that while some of the people analyzed were recent university graduates, others completed their degrees decades ago. The education variable is "highest level of education of [a] person" 16 and up, but by selecting for bachelor's degrees, the de facto age lower cut-off is about age 21 .

The income assessed by Giles and Drewes was for 1992, meaning that graduates from the fall convocations of 1992 only had the opportunity for two or three months work even if they secured employment quickly. Since Giles and Drewes transformed salaries into hourly equivalents, the income reports are meaningful, even for these recent entrants. For the present study, although I begin with 1992 income, for reasons explained below, I then examine incomes for 1996, near the end of the SLID longitudinal cycle (five years later, to replicate Giles and Drewes, rather than the full six years of the SLID longitudinal design). The income examined is remuneration from employment, either as an employee 
or as self-employed. ${ }^{2}$ Main conclusions do not differ if self-employment is excluded, but I reasoned that self-employment is still labour market activity in which a value is being placed on a person's human capital stock and services rendered. Income is logged (natural $\log$ ) and then transformed back to dollars for the descriptive presentations.

The analysis being replicated compared humanities and social sciences against applied programs, largely in science and technology (Giles and Drewes, 2002, p. 20). That captures much of the "two cultures" distinction from the writer C.P. Snow (1959). The two most notable developments over the 12 years from 1993 to 2005 were the growth of more applied, subject-matter specific, social sciences and the rising enrolments in business/commerce programs. Although beginning with just two of the categories-applied versus non-applied-later in the analysis I subdivided arts and social science into generic skills versus applied skills. Business programs were classified into a category of their own since they straddle the worlds of words and pictures versus numbers (to give an admittedly crude expression to Snow's distinction). In the SLID data, field of study is coded into the Classification of Instructional Programs (Statistics Canada, 2011). Thus, a field such as "philosophy and religious studies," category 38 in the so-called "series group" version of the code included in the research data centre (RDC) master file (a two-digit version of the full CIP), in my categorization was "liberal arts, non-applied." In contrast, "education" (category13), was coded as "liberal arts, applied." I began by also differentiating applied from non-applied fields within science and technology (which is done by Adamuti-Trache, Hawkey, Schuetze, and Glickman, 2006, p. 56), but later abandoned the distinction. Small cell sizes became a problem, and results did not seem to differ between the more- versus less-explicitly applied fields in natural science and technology. The recode of the CIP appears in endnote $3 \cdot{ }^{3}$

As a final procedural note, for graphical presentations I moved to three age categories (29 and under, 30-44, 45 and over) in place of Giles and Drewes' four. In the later multivariate models, age was coded in years.

\section{Analytical Plan}

The presentation of results begins with a replication of the more descriptive data from Giles and Drewes. Then, in recognition of the increasing publicity around bachelor's degree holders in the liberal arts proceeding on to acquire further educational credentials, such as community college diplomas or further university degrees (see Globe and Mail, May 9, 2011, p. A8-9; May10, p. A4), I switch to a modelling approach and examine these further aspects of income attainment for the university educated in the early 21st century. Issues of statistical significance are handled within this multivariate section. The descriptive tabulations do not differentiate by sex, in the interests of preserving cell counts. Sex, which of course is closely tied with students' selections of fields of study and with income, enters the analysis within the later multivariate work.

\section{Results}

\section{Replication of Liberal Arts Catch-up Finding}

Table 1 is closely modelled on Table 1 from the Giles and Drewes article, presenting descriptive information for the baseline year of SLID panels 1 and 5, dividing the sample by humanities and social sciences (all counted as non-applied) versus applied programs. 
As they did (see Giles and Drewes,(2002, p. 21, see footnote to their Table 1), the cases complete over five years are examined here, even though this descriptive profile pertains to the initial year of each panel. My table begins with sample size, mean age, proportion of women, number of jobs held, and number of jobless spells. Giles and Drewes showed major groups for industry and occupation, but I simplified here by showing proportion in National Occupational Classification (NOC) skill levels o (management occupations) and 1 (occupations usually requiring university education) along with occupational prestige scored in the system described in Goyder and Frank (2007). For this table Giles and Drewes' two-fold field classification has been reproduced as accurately as possible. ${ }^{4}$

Table 1.

Descriptive Profiles, Bachelor's Degree Holders, 1993 and 2005 SLID

\begin{tabular}{lcccc}
\hline & \multicolumn{2}{c}{ 1993 SLID } & \multicolumn{2}{c}{ 2005 SLID } \\
\cline { 2 - 5 } & Not Applied & Applied & Not Applied & Applied \\
\hline Sample size (N) & 1,043 & 774 & 1,341 & 1,059 \\
\hline Mean Age, January 1 & 40.2 & 39.5 & 43.9 & 42.2 \\
\% female & 56.9 & 37.4 & 63.7 & 44.3 \\
Jobs held* & 0.924 & 0.965 & 0.952 & 1.025 \\
Jobless spells* & 0.246 & 0.222 & 0.263 & 0.289 \\
\% highest skill level* (o,1 in NOC) & 61.5 & 64.8 & 56.1 & 64.4 \\
Occupational prestige score* & 69.92 & 69.79 & 68.85 & 69.90 \\
\hline
\end{tabular}

Notes. $\mathrm{N}$ is unweighted, everything else weighted (with downweight back to sample $\mathrm{N}$ ); the "reference years" are 1992 for Panel 1 and 2004 for Panel 5. The standard deviations on the prestige scale are about 7.5 points. * denotes numbers in year 1.

Twelve years is only half a generation and the overall proportion of graduates in applied versus non-applied fields crept up just minutely, from $42.6 \%(774 /(1,043+774))$ to $44.1 \%$. The average age of bachelor's degree holders increased by a couple of years between 1993 and 2005, reflecting the demographic trend toward an aging society. The percentage of females in applied programs is edging toward parity: the 1993 total was $37 \% \mathrm{fe}-$ males graduating from applied programs, rising to $44 \%$ by 2005 , reflecting the increasing dominance of higher education by women (a point examined in greater detail, and with some qualifications, in Andres and Adamuti-Trache (2007). Slightly more job-shuffling can be seen in 2005 than in 1993. Jobless spells increased for both field-types, but notably for applied program graduates. The growing normalcy of frequent job changes is of course part of the definition of the $21^{\text {st }}$-century economy. Finally in this descriptive profile, there is erosion of bachelor's degree occupancy of the top NOC skill levels for occupations, especially among humanities and social science graduates, but with a little slippage among applied graduates too (although the prestige scores only capture the loss for humanities and social science graduates).

Next, a set of graphical presentations on income, again modelled on Giles and Drewes. Figures $1 \mathrm{a}$ and $1 \mathrm{~b}$ give a baseline replication of their maturation finding. All the graphs turn log incomes back into dollars inflated to 2008 values. For the workforce as a whole, income should increase with age, reflecting increments due to job experience, seniority, 
and progress through the ranks. Admittedly, this is an assumption pertaining to the sector of the labour force once referred to as "white collar" rather than to "blue collar" workers, but it is appropriate since we are examining university graduates only. The exciting point noted by Giles and Drewes is that, while the incomes reported for 1992 for applied program graduates increased just slightly across the age bands, those for non-applied graduates climbed much more rapidly so that by age 45 an initial disadvantage had been closed. Figure 1a reproduces Giles and Drewes' finding using my slightly different coding procedures. Figure $1 \mathrm{~b}$ examines catch-up for 2004 income, from the Panel 5 version of the SLID. For 2004, there is no sign of the crucial catch-up pattern. Instead, the age 45 and over applied program graduates have nearly broken the $\$ 35$ an hour barrier, moving to $\$ 34.93$. Pessimists within the popular media and academe have evidence to support their contentions.

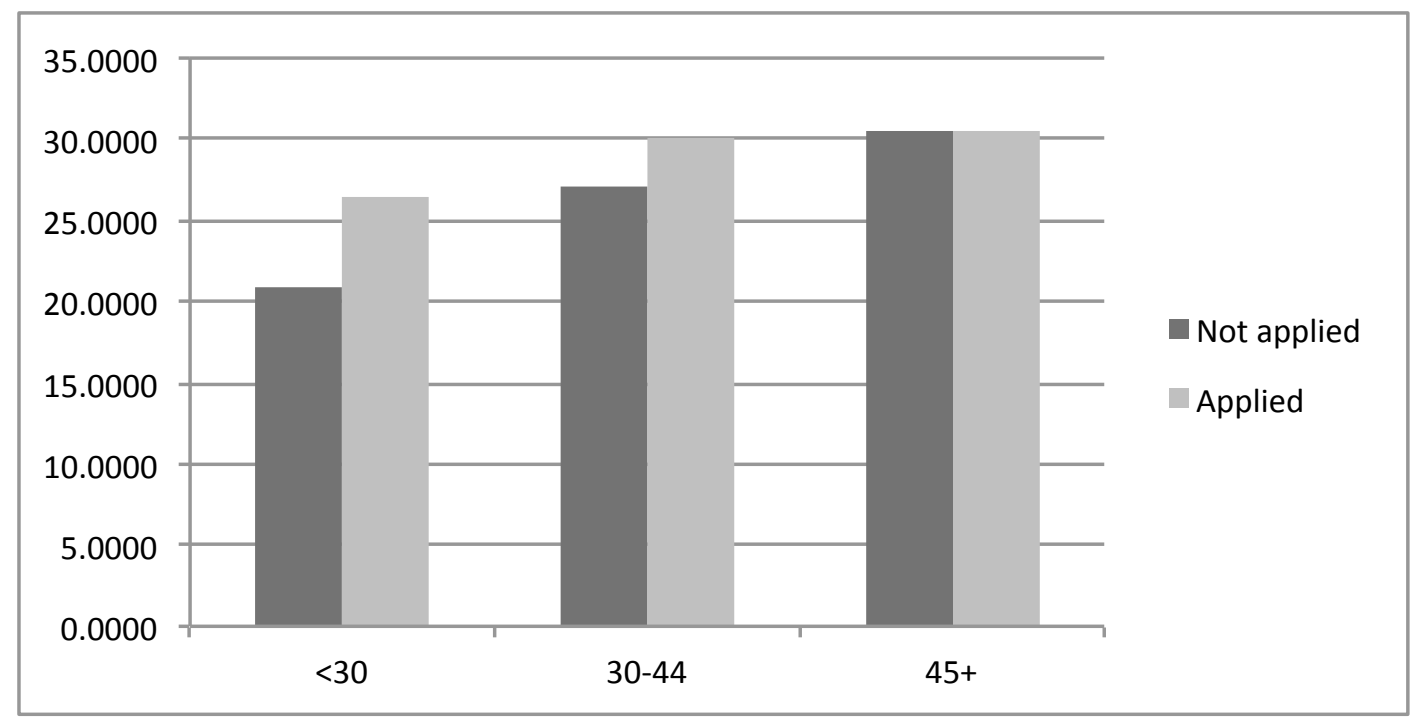

Figure 1a. 1992 incomes (adjusted to 2008 \$)

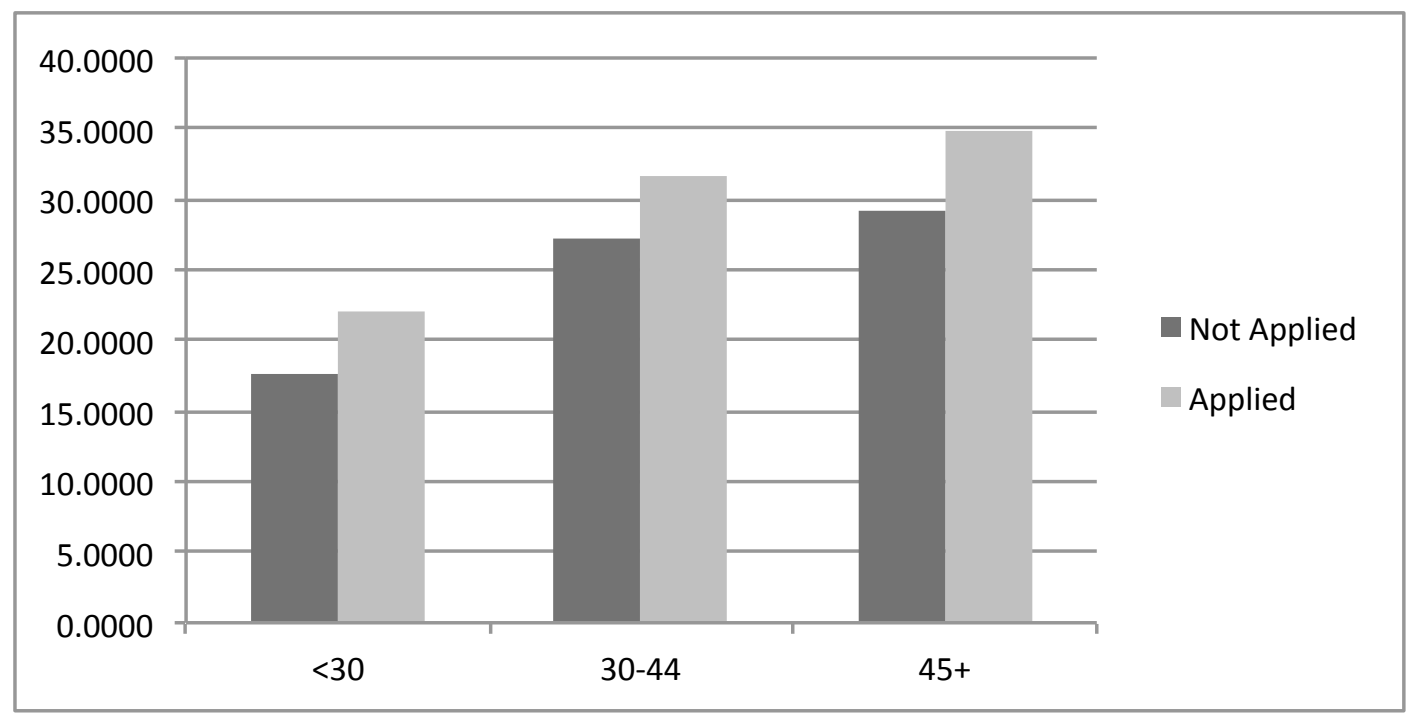

Figure 1b. 2004 incomes (adjusted to 2008 \$) 
Mindful of findings by Adamuti-Trache, Hawkey, Schuetze, and Glickman (2006), I felt uneasy resting conclusions exclusively on an income defined, for some, just months after completion of the degree. There would be labour force churning and consequent income instability at play among those having just entering the workforce. Liu, McCloy, and De Clou (2012) documented the improvement in labour market outcomes for bachelor's graduates between years two and five since graduation. I therefore returned to the Panel 1 data, looking now at 1996 income by age band. Since these are the respondents from 1993 being resurveyed in 1997 (and reporting income for 1996), the age bands have shifted. The lowest band would contain nobody younger than age 25 (the youngest 1993 respondent being aged 21). The middle-age band 30 to 44 shifts to 34 to 48 , and those aged between 65 and 69 in 1993 have moved out of the 1997 tabulation. History and maturation are mixed up here, but a robust finding of liberal arts catch-up should survive the juggling of years and ages. In this approach to the Panel 1 data, shown as a bar graph in Figure 2a, the pattern is not as neat as for 1992, but catch-up is still discernible. The gap between under 34 widens to 34 to 48 , but closes for those 49 and over, leaving the essence of the catch-up conclusion intact.

Repeating (in Figure 2b) the analysis for Panel 5's 2008 incomes, as reported in 2009, the no-catch-up pattern from 2004 is reproduced although incomes for applied and nonapplied graduates alike were lower in this year of financial crisis (the stock market crash, Lehman Brothers bankruptcy, etc.). Summarizing, the Giles and Drewes' finding of liberal arts catch-up can be reproduced for Panel 1, the period they studied, even using some alternative procedures. It is thus a robust finding for the 1990s. For Panel 5, covering 2004 and 2008 income, catch-up is no longer visible.

\section{Strategies Pursed by Liberal Arts Graduates: Further Postsecondary Education}

Discussions of socioeconomic attainment by field of university study need, as Finnie (2001) noted, to consider postsecondary education subsequent to the B.A., especially the "re-cycling" option described in Walters (2003), whereby university graduates enroll in institutions such as community colleges. In Lowering Higher Education, Côté and Allahar (2011, p. 65) comment that, "more and more graduates are seeking multiple degrees and diplomas." I compared the incidence of such strategies for panels 1 and 5 of the SLID, results shown in Table 2. It is at this point that the four-fold classification of field, outlined earlier, is introduced. Thus Table 2 classifies field by humanities and social sciences sub-divided into non-applied versus applied, alongside business and the STEM (sciencetechnology-engineering-mathematics) cluster.

The first line tallies those receiving a "non-university postsecondary diploma/certificate" (from variable "agrnun18" in the codebook) at an age later than the age at which the respondent received the bachelor's degree reported in the code for "highest level of education of person" ("hleved18," for the first year of the panel). These are postsecondary qualifications received after a first bachelor's, over the (surveyed) lifetime of the respondent. Graduate study is excluded in these tabulations by including only those whose highest level of education was still bachelor's by the end of the cycle of SLID interviews. Most notable here is the increase from 15.2 to $21.2 \%$ of graduates of humanities and social science non-applied programs who have recycled their credentials. In both years, graduates from applied humanities-social science programs or from business are least likely to proceed from their bachelor's university degree to a non-university postsecondary course of study. 
Figure 2a. 1997 incomes (adjusted to 2008 \$)

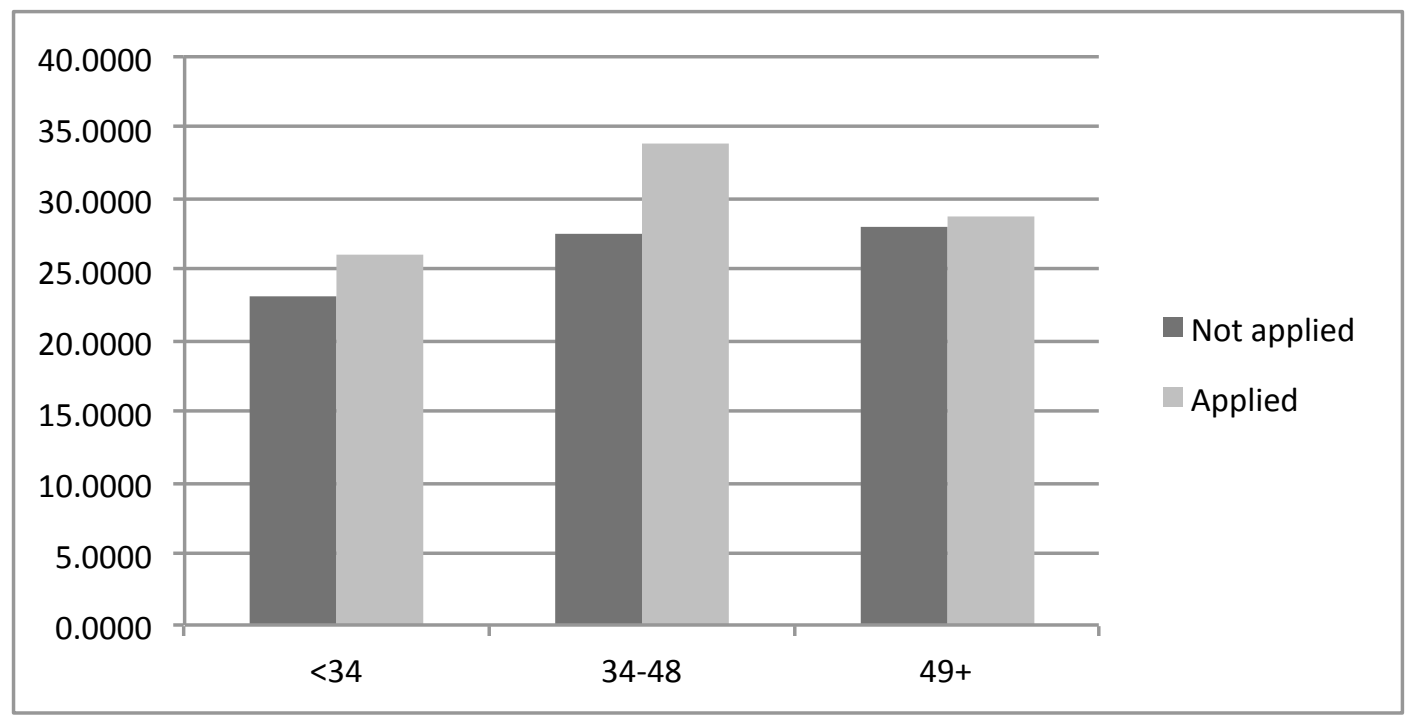

Figure 2b. 2008 incomes (adjusted to 2008 \$)

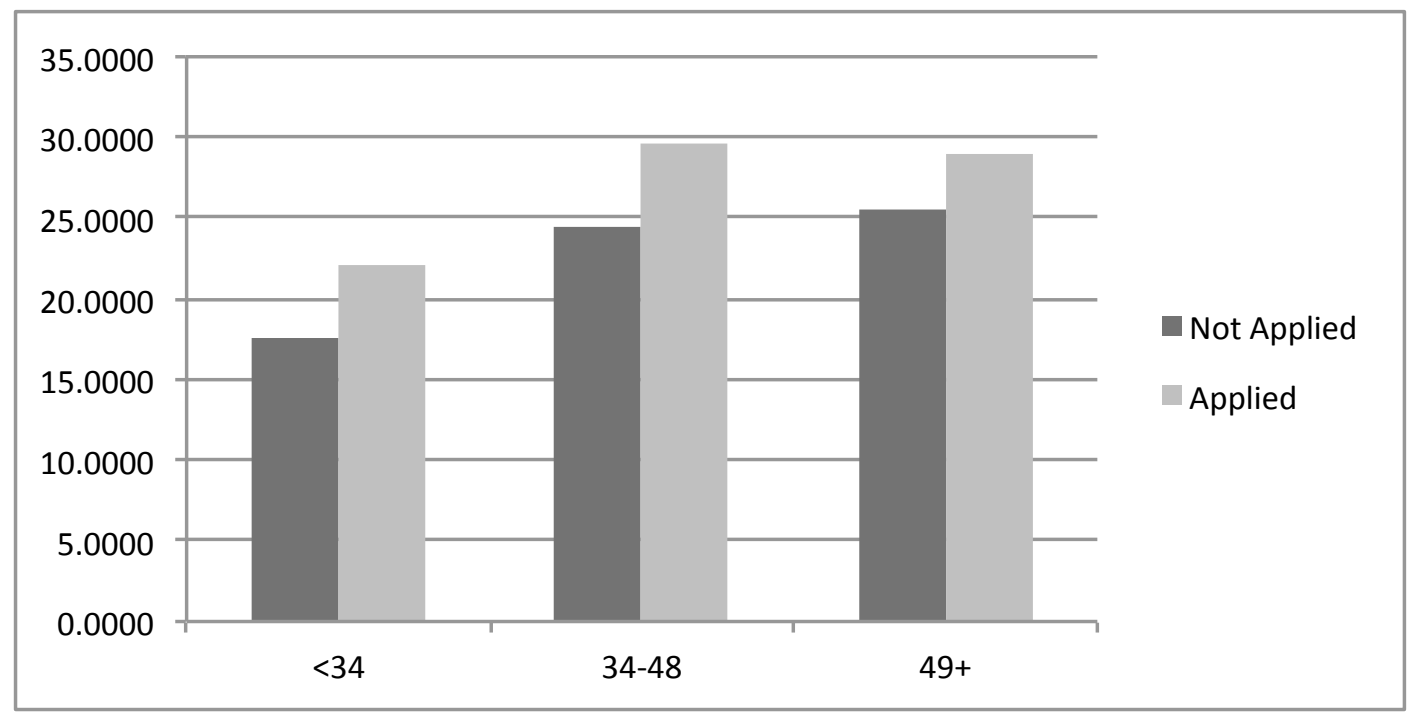

A finer-grained analysis of further postsecondary education can be taken from the longitudinal feature of the SLID, whereby respondents are reinterviewed for several years. Each year, they are questioned about the acquisition of further educational qualifications ("rccoll2O," from the codebook). Here, the incidence is highly dependent on age because most of those seeking further education are younger. It would make less sense for a person late in his or her working life to go back into the educational system. Rather than cut off the age range for the tabulation, I built the lower portion of Table 2 by using logistic regression equations in which acquiring a college certificate, for example, was predicted from age together with the four-fold field classification already described. For each of the two SLID panels, there is a separate logistic regression computation for each educational credential. Predicted probabilities from the model were calculated, choosing ages 30, 40, and 50 as three arbitrary points to illustrate the age trend. 


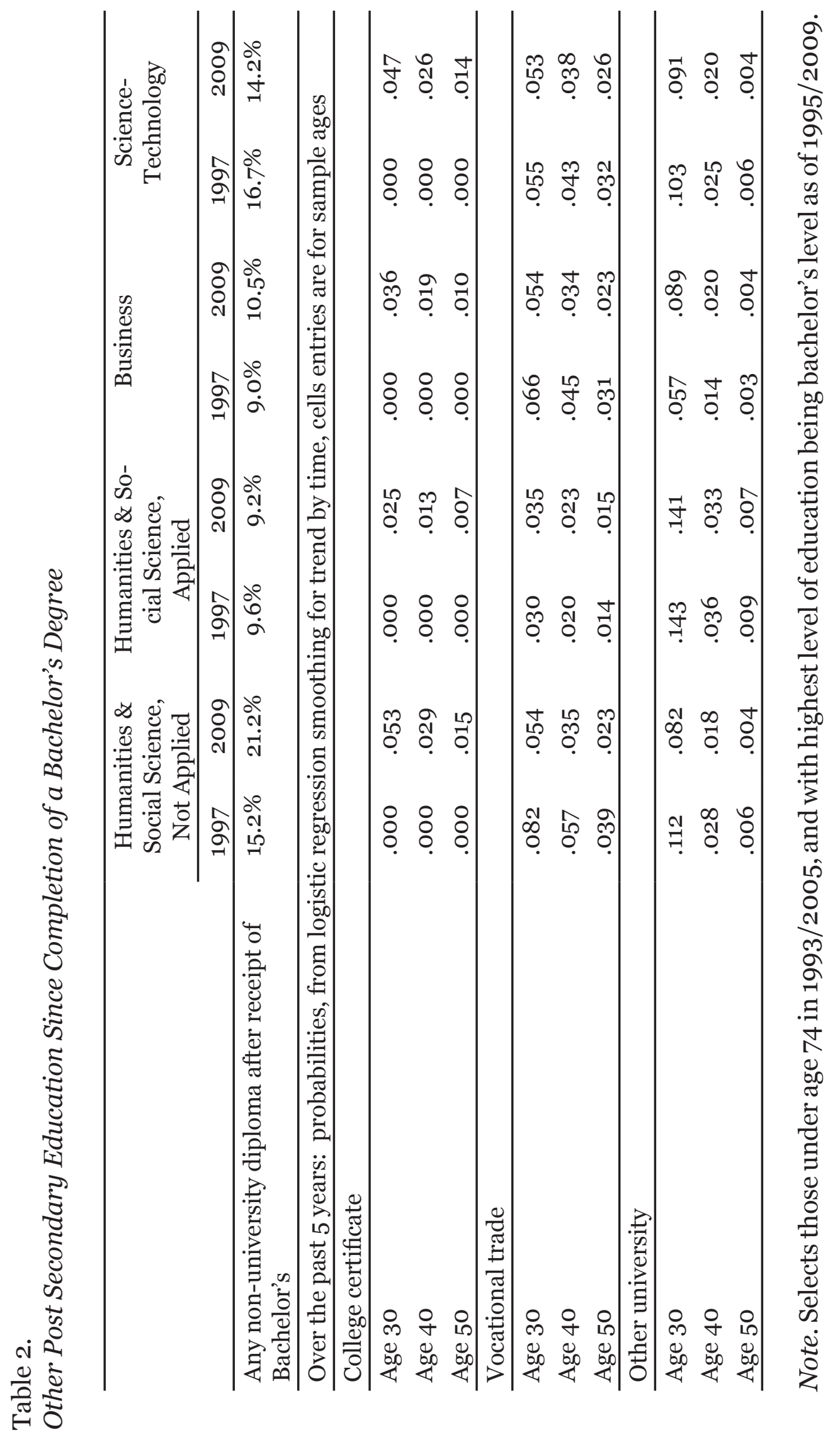


The interest in constructing this part of the table lies in whether the younger university graduates in the 2000 s panel became especially likely to return to the educational system on a horizontal or even "downward" basis. There is some support for that expectation. None of the nearly 2,000 bachelor's degree respondents from Panel 1 (1993) had by 1997 acquired a college certificate. By 2009, some $5 \%$ of those aged 30 with a humanities/social science degree in not-applied fields had. Remember, this is a fitted value from a logistic regression model, not an actual one, but if one goes into the dataset and tabulates by age, the figure is about the same. These are the cases Margaret Wente writes about concerning the poor career prospects of liberal arts graduates, contending that a return for more practical education at the college level is typical for the current generation (Globe and Mail, March 7, 2009, p. A21). Five out of every hundred seems quite a small incidence, and nearly as many (4.7\%) science-technology undergraduate degree holders followed the same strategy. Another $5 \%$ or so from the liberal arts (non-applied) pool acquired a non-college "vocational" or "trade" certificate. I have encountered similarly small figures in the Youth in Transition Survey (YITS) (Goyder, 2009, Table 2). The more dominant pattern from Table 2 is the likelihood of bachelor's degree holders returning to university within the five years examined to pursue some further (but still bachelor's level) university qualification. Again, the probabilities are highest for younger respondents who have the most time to realize the economic benefits of qualification upgrades.

Even among those who stay within the university system, there is a complex story around field of study. To give some additional figures, not part of the tables, I was surprised when working through these data, how many people have completed more than one bachelor's-level degree or credential during their lives, switching fields in the process. In Panel 5, only 47\% of those with some form of university credential (codes 2, 3, or 4 on variable "certype19") had but one such credential. This percentage covers only university bachelor's-level diplomas or degrees, since both graduate degrees and non-university postsecondary categories are set aside in this computation. Of those in Panel 5 with more than one university bachelor's-level credential, a large percentage- $71 \%$-had switched fields (within my quite broad four-fold categorization) somewhere along the trail of undergraduate studies. Estimates of field-migration are similar in the YITS data (Goyder and Casey, 2013).

These patterns were equally distinct in Panel 1, with only 37\% of those with some form of university credential having only one such credential, and $87 \%$ having at least one field switch. In both panels, it is those with non-applied humanities and social science first fields who are most likely to switch.

\section{Regression Model (L 2)}

I am not going to analyze the incomes of those who do versus those who do not pursue further postsecondary over the span of years covered within the SLID longitudinal design. The numbers are too small to give meaningful results, and the period is not long enough to allow a decisive pattern to show. A person might sacrifice immediate income, working part-time while attending a post-bachelor's college program, looking for enhanced future employment prospects. It is, however, meaningful to examine the consequences of further qualifications over the longer term (i.e., the upper row of Table 2, where $15.2 \%$, for example, of humanities and social science, non-applied, people from 1997 reported having a non-university diploma acquired after the bachelor's university degree). 
An OLS (ordinary least squares) regression analysis of log income addresses this. Shown in Table 3, the model has the four categories of field of study, and adds further education along with age and sex, the latter two variables for maintaining continuity with the Giles and Drewes analysis. Canada presents an analytically cleaner case for such analysis than does the United States because to the north there is not the same need to differentiate between types of university (as Goyette and Mullen, 2006, do). Age is not a factor alongside the other predictors in the model although in a bivariate examination age shows increasing incomes as the years pass (there is a small positive zero order correlation in panels 1 and 5, slightly larger in Panel 1). In 1997 females still had lower predicted income, similar to other research of that vintage (e.g., Morgan, 2008, analyzing U.S. data), but this income disparity ceased to any statistically significant degree by 2009 .

Table 3. Regression Analysis

\begin{tabular}{lcccc}
\hline & \multicolumn{2}{c}{1996 Log Income } & \multicolumn{2}{c}{2008 Log Income } \\
\cline { 2 - 5 } & \multicolumn{1}{c}{$\mathrm{B}$} & (s.e.) & $\mathrm{B}$ & $($ s.e. $)$ \\
\hline Age & .004 & $(.004)$ & -.001 & $(.003)$ \\
Sex & $-.252^{* * *}$ & $(.064)$ & -.089 & $(.050)$ \\
H \& SS not-applied & -.064 & $(.068)$ & $-.216^{* *}$ & $(.080)$ \\
H \&SS applied & -.132 & $(.083)$ & $-.153^{*}$ & $(.061)$ \\
Business & -.012 & $(.085)$ & -.115 & $(.094)$ \\
Other postsecondary non-university, & -.178 & $(.073)$ & -.077 & $(.073)$ \\
over career & & & & \\
(Reference category: STEM) & & & & \\
Constant & 3.385 & $(.176)$ & 3.724 & $(.144)$ \\
\hline
\end{tabular}

${ }^{*} \mathrm{p}<.05,{ }^{* *} \mathrm{p}<.01,{ }^{* * *} \mathrm{p}<.001$ (bootstrapped)

When looking at field of study, the income loss from having a humanities and social sciences, non-applied, background is far larger in 2008 than 1996 (coefficient of -.216, $\mathrm{p}<.01$ vs. $-.064, \mathrm{p}>.05)$. Neither coefficient for the two types of humanities or social degree in 1996 passes significance, meaning they can best be set at zero. As we know, in this earlier panel high income for those aged 45 and over is offsetting low early-career income among liberal arts graduates. The 2008 effect for applied humanities and social science fields is $(\mathrm{p}<.05)$ negative in this computation, which compares against STEM graduates as the baseline. In one of the more surprising findings of this analysis, further non-university postsecondary education does not show the expected connection with higher income. Instead, the coefficients are negative, denoting lower income. From the non-statistical significance for both years, those coefficients too could be set to zero as the best population estimate. But even so, zero effect on income cannot be what was intended by those graduates of university programs who have acquired subsequent further postsecondary qualifications at the non-university level. That does not change if one selects only those with not-applied humanities and social sciences university degrees and then re-examines the effect of further non-university postsecondary degrees. As Coates and Morrison (201, p. 35) said, "Forget the B.A.: Now you need two degrees" (meaning the second one at the graduate level). 


\section{Conclusion}

The analysis just described differs from what would be seen from data sets such as the National Graduates Survey (NGS) or the YITS, because SLID is examining the entire adult population. NGS, looking at recent graduates, skews toward youth and YITS even more so since it examined a cohort (in cohort B) aged 18 to 20 as of 2000 and followed them for eight years. In comparing the 1993 to 1997 SLID respondents with those from 2005 to 2009, we have a kind of demographic glacier, constantly both acquiring and losing eligible cases. Theoretically (even if the probability is minute), some of the Panel 1 respondents could also have been captured in the Panel 5 sampling. Those who died in the interim or who aged beyond the 69 years cut-off for the income-recording variable could not have been included, nor could people who were minors in 1993 and only reached age 21 (the lower age cut-off in my tabulations) after 2005. Those aged between 21 and 57 in 1993 are "present" (although almost always not literally, but implicitly by another respondent of the same age) in the 2005 data as 33 - to 69-year-olds. That is 24 years worth of the 48 years spanned by the range 21 to 69 . All this puts inertia into the analysis, not present in a time series of cross-sections for recent graduates, yet the changes reported have been severe enough to overcome that.

The promising Giles and Drewes finding of catch-up by liberal arts graduates cannot be found in more recent tabulations. Why? First, it's not a "recession finding." It is true that the 2008 incomes analyzed coincided with a sharp fall in stock markets, precipitated by the crash in the U.S. housing market around "sub-prime," non-solvent mortgages. People (even in Canada, via fallout) would have been losing incomes in that year due to failed businesses, lay-offs, early retirements, and so forth. Recall, however, that there was no catch-up in 2004 either. With respect to the ineffectiveness of non-bachelor's credentials gained post-bachelor's degree, as a robustness test I repeated the analysis moving the income year to 2006, which is just before the stock market crash, back from the 2008 reference year in Table 3. The null income increments for post-bachelor's college credentials remained. Neither is it the case that today's liberal arts university graduates exchange lower incomes for higher prestige jobs. I repeated the analysis using the scale of occupational prestige noted in Table 1 . The scale is sensitive to public approval of occupations such as teacher or social worker, which are socially important but modestly paid, but catch-up cannot be found within this scale either.

We come by default, then, to the feeling that a historical change has taken place in how university education credentials lead to socioeconomic outcomes. People with nonapplied degrees still find jobs and earn incomes (indeed, my analysis is restricted to such people; the long-term unemployed would get filtered out of the model), but the incomes are lower and persist in being lower, relative to applied program graduates, as people move through the working life cycle. This change is consistent with two observations about the social history of the past two decades.

First, Canadian society and its economy become ever more science and technology fixated. This shift could be seen as an economic imperative, the interpretation articulated by Walters and Frank's review of these issues (2010, p. 6-7) when they observe, "some have asserted that this 'new' economy requires workers with highly specialized skills rather than workers with the 'soft' skills typically associated with a liberal arts education." More 
sociologically, the issue may be perceptual and that the valuation placed on liberal arts generic skills is slipping away from the minds of those making decisions about job appointments and promotions. In 1993, the reference year for Giles and Drewes, Apple was a floundering company and its "i" technologies still lay in the future. The Internet was far less developed. "Data mining" for marketing purposes was in its infancy yet now receives prominent business news coverage (e.g., The Economist, 2013). It may thus be that shift has occurred in the kind of skills valued by employers. Even if the value placed on technological skills is misplaced and technocratic, it is real in its consequences.

Second, I can echo those such as Coates and Morrison (2011, p. 35-37) who have noted the large supply of university graduates and especially university graduation by high school graduates who, a generation ago, would not have been regarded as universityready (the latter being the Côté and Allahar argument). Canadian universities, in contrast to those in the US, are more selective within programs than between universities. Books on "college admissions" such as Steinberg's (2002) or Stevens' (2007) could not be written about Canada. There is no escaping the fact that those admitted to science and technology programs are, on average, academically stronger than those in humanities and social science departments. This is another contrast to the US, where students in the "Ivies" such as Yale or Harvard have written their ticket simply by gaining admittance (Soares, 2007). These students can study poetry or philosophy for four years and still have their pick of jobs simply because their numbers are so small and by the fact that admittance to the elite school attests to their enriched background and academic ability, a point argued by Gladwell (2005) and termed "selection effect" by Gerber and Cheung (2008, p. 301).

Canadian faculties of humanities or social sciences, or composite faculties of arts are not in the Yale or Harvard business of producing only a tiny supply of graduates who already have a great deal going for them from family-derived social and cultural capital, or from sheer scholarship-winning ability. Nor are Canada's bachelor's graduates a eugenic elite from upper-class interbreeding, as Murray (2012) claims the graduates of elite private American universities are. Graduates of liberal arts programs in Canadian universities are a mix: some with great ability and aptitude for the subject matter revered by instructors of humanities and social science courses, but others there by default-the students Allahar and Côté discuss-people not ready for university, there due to the pressure of cultural expectations or prestige attributions, or in fulfilment of a parental agenda. As a reviewer reminded me, the problem of under-qualified students in university is exacerbated by a long-running trend of declining hours per week spent on studying. There is a broad-based erosion that is consistent across sociological categories of a student, involving norms around entitlement to leisure alongside the pressure on low-income students to finance rising tuition fee costs with part-time work (Babcock and Marks, 2011). The catch-up finding might emerge if honours degree holders could be separated from general degrees, but the SLID does not allow that distinction, nor are grades part of the dataset.

No wonder it is so hard to sort out the value of a liberal arts education for occupational success. It was an inference from a form of ecological correlation to say that catch-up demonstrated the value of liberal arts education. It would be just as much an ecological fallacy to say that the non-catch-up early in the $21^{\text {st }}$ century shows that liberal arts skills have less long-term value than applied program skills. The erosion of the catch-up effect does, however, shift the burden of proof back onto educators in the humanities and social 
sciences. More attention to measurement of generic skills gained by a liberal arts education (a skills equivalent to the focus on engagement in the National Survey on Student Engagement) might be useful. In the meantime, there is a need for caution around what is said on the "why arts" webpages of faculties of humanities and social sciences across Canadian campuses.

\section{Notes}

1. A reviewer questioned the omission of holders of graduate degrees in this analysis. Admittedly much of the academically top end of the distribution for liberal arts students (documented in the US in Goyette and Mullen, 2006, or Torche, 2011) is thus set aside. In the SLID data, roughly a third of all bachelor's degree holders had gone on to a graduate or professional degree. The topic of the present research is mainly with the other two-thirds, the university graduates with the broken dreams who are the source of so much media attention.

2. I used wgsal42 (wages and salaries before deductions), which is employment income for individuals aged 16 and over. The occupation variable caps age at 69, meaning that wgsal42 also is capped at age 69. Income was transformed into hourly equivalents using the "hpw" (hours paid work) variable. In operationalizing income, I lingered over discrepancies between income from employment by others versus income from self-employment. Simply adding self-employment earnings to working-for-others incomes produced some wild distortions. With some of the income reports coming from tax returns, one encounters occasional huge negative incomes from self-employment. Since these were clearly tax-minimization strategies, I developed the following algorithm: take the greater of earng42 (all earnings) and wgsal42 and if tied, use earng 42. If the resulting variable is a nonsensical $\$ 1$ an hour or less, set to missing (which affects only a handful of cases).

3. CIP recode: $\operatorname{ci1g} 19(1=11)(3=11)(4=11)(05=00)(09=01)(10,11=11)(12=01)$ $(13=01)(14,15=11)(16=00)(19=11)(21=11)(22=01)(23,24=00)(25=01)(26$, $27=10)(29=11)(30=00)(31=01)(32,33=00)(34=11)(35=00)(36=01)(37$, $38,39=00)(40=10)(41=11)(42=00)(43=01)(44=01)(45=00)(46=01)(47$, $48,49=11)(50=01)(51=11)(52=31)(54,55=00)(60=11)$. ci1g19 is "CIP - Series groupings."

Liberal arts, non-applied is 0o; liberal arts, applied is 01; science and technology, nonapplied is 10; science and technology, applied is 11 (with 10 and 11 merged in analysis reported here); business degree is 31 .

4. My numbers are not exact reproductions of Giles and Drewes', because their version of the SLID (possibly conducted at Statistics Canada, before the RDC program came in) has field of study variable "fsunag20," defined in the codebook as "principal field of study university major unit group." In the RDC version I was working from "ci1g19". Both are re-codings of the Classification of Instructional Programs. With the RDC version, I had to use the "educational certificates" file, which has as many lines of data per respondent as postsecondary certificates held (e.g., a person who attends community college, then gets one university degree, has two lines in the dataset). I extracted the lines where "certyp19=3" (university bachelor's degree), coded variable ci1g19 as described above, then pasted into the "person" file of one line per respondent. Some 
20 respondents reported two or even three bachelor's degrees, an interesting group, but of insufficient number to support separate analysis. I "hand-weeded" the data to assign one degree, the most recent one, per respondent. Usually the second bachelor's was more "applied" than the first. Typical progressions were from humanities-social science, non-applied, to applied; or from either humanities-social science into business. I don't think the SLID questionnaire is sensitive to double majors, which Zafar (2011) says are important. Question ED_Q140, on education during the reference period within the survey dates, reads: What was the major field of study or specialization? (Statistics Canada, 2012). EP_Q050, on educational history (prior to entering SLID panel) uses the same phrase. Zafar (2011, p. 293) says that most double majors are in "related fields" (which would remain within the same category in my coding).

\section{Acknowledgements}

This work was funded by an SSHRC grant, and it was made possible through access to SLID master files at Statistics Canada Research Data Centres, initially at the Southwestern Ontario Research Data Centre at the University of Waterloo, later at the McMaster University Research Data Centre. Thanks to the analysts at both centres. An earlier version of this paper was presented at the CSSHE Conference (within Congress 2012), Waterloo, May 2012, under the title "Liberal Arts Education and Income Attainment: At a Crossroad." Thank you, CJHE reviewers, for your comments, and thanks to Torben Drewes for his interest in the project.

\section{References}

Andres, L., \& Adamuti-Trache, M. (2007). You've come a long way, baby? Persistent gender inequality in university enrolment and completion in Canada, 1979-2004. Canadian Public Policy, 33(1), 93-116.

Adamuti-Trache, M., Hawkey, C., Schuetze, H.G., \& Glickman, V. (2006). The labour market value of liberal arts and applied education programs: Evidence from British Columbia. Canadian Journal of Higher Education, 36(2), 49-74.

Axelrod, P., Anisef, P., \& Lin, Z. (2001). Against all odds? The enduring value of liberal arts education in universities, professions and the labour market. Canadian Journal of Higher Education, 31(2), 47-77.

Arum, R., \& Roska, J. (2011). Academically adrift: Limited learning on college campuses. Chicago: University of Chicago Press.

Babcock, P., \& Marks, M. (2011). The falling time cost of college: Evidence from half a century of time use data. The Review of Economics and Statistics, 93(2), 468-78.

Coates, K.S., \& Morrison, B. (2011). Campus confidential: 100 startling things you don't know about canadian universities. Toronto: Lorimer.

Côté, J. E., \& Allahar, A.L. (2007). Ivory tower blues: A university system in crisis. Toronto: University of Toronto Press.

Côté, J.E., \& Allahar, A.L. (2011). Lowering higher education: The rise of corporate universities and the fall of liberal education. Toronto: University of Toronto Press. 
Davies, S., \& Guppy, N. (1997). Fields of study, college selectivity, and student inequalities in higher education. Social Forces, 75(4), 1417-1438.

Drewes, T. (2002). Value added: Humanities and social sciences degrees. Ontario Confederation of University Faculty Associations Forum, Spring issue: 10-12.

Finnie, R. (2001). Fields of plenty, fields of lean: The early labour market outcomes of Canadian university graduates by discipline. Canadian Journal of Higher Education, 31(1), 141-76.

Finnie, R., \& Frenette, M. (2003). Earnings differences by major field of study: Evidence from three cohorts of recent Canadian graduates. Economics of Education Review, 22(2), 179-92.

Frank, K., \& Walters, D. (2012). Exploring the alignment between postsecondary education programs and earnings: An examination of 2005 Ontario graduates. Canadian Journal of Higher Education, 42(3), 93-115.

Freeman, R.B. (1971). The labor market for college-trained manpower. Cambridge, Mass.: Harvard University Press.

Freeman, R.B. (1976). The overeducated American. New York: Academic Press.

Frenette, M. (2004). The overqualified Canadian graduate: The role of the academic program in the incidence, persistence, and economic returns to overqualification. Economics of Education Review, 23(1), 29-45.

Gerber, T., \& Cheung, S.Y. (2008). Horizontal stratification in postsecondary education: forms, explanations, and implications. Annual Review of Sociology, 34:299318.

Gladwell, M. (2005). Getting in. The New Yorker, October 10.

Giles, P., \& Drewes, T. (2002). Liberal arts degrees and the labour market. Educational Quarterly Review, 8(2), 19-25. Statistics Canada Catalogue no. 81-003.

Goyder, J. (2009). From levels to combinations: Examining new vocational strategies within post-secondary education. Presented at the conference Using Social Statistics to Illuminate the Issues, Processes, and Outcomes in Higher Education: International Viewpoints, December 7-9 2009, Montreal, QC.

Goyder, J., and Casey, R. (2013). An analysis of field of study choice among Canadian university students. Presented at the annual meetings of the Canadian Sociological Association, Victoria, BC.

Goyder, J., \& Frank, K. (2007). A scale of occupational prestige in Canada, based on NOC Major Groups. Canadian Journal of Sociology, 32(1), 63-83.

Goyette, K.A., \& Mullen, A.L. (2006). Who studies the arts and sciences? Social background and the choice and consequences of undergraduate field of study. Journal of Higher Education, 77(3), 497-538.

Heisz, A. (2001). Income prospects of British Columbia university graduates. Cat. no. 11Foo19MPE, Number 170. Ottawa: Statistics Canada. 
Liu, S., McCloy, U., \& DeClou, L. (2012). Early Labour Market Outcomes of Ontario College and University Graduates, 1982-200o. Toronto: Higher Education Quality Council of Ontario.

Livingstone, D. W. (1999). The education-jobs gap: Underemployment or economic democracy? Aurora, ON: Garamond.

Livingstone, D. W. (2009). Education and jobs: Exploring the gaps. Toronto: University of Toronto Press.

Morgan, L.A.(2008). Major matters: A comparison of the within-major gender pay gap across college majors for early-career graduates. Industrial Relations, 47(4), 625-650.

Murray, C. (2012). Coming apart: The State of White America, 1960-2010. New York: Crown Forum.

Soares, J. A. (2007). The power of privilege: Yale and America's elite colleges. Stanford: Stanford University Press.

Snow, C.P. (1959). The two cultures. London: Cambridge University Press.

Statistics Canada. (2005). Survey of labour and income dynamics: A survey overview. Cat. 75Foo11XIE.

Statistics Canada. (2011). Classification of instructional programs (CIP) Canada. Catalogue 12-590X Retrieved from http://www.statcan.gc.ca/pub/12-590-x/12-590x2012001-eng.pdf

Statistics Canada, 2012) http://www23.statcan.gc.ca/imdb-bmdi/instrument/3889 Q6 V5-eng.pdf, accessed 28 August 2012).

Steinberg, J. (2002). The gate-keepers: Inside the admissions process of a premier college. New York: Viking.

Stevens, M. L. (2007). Creating a class: College admissions and the education of elites. Cambridge, Mass.: Harvard University Press.

The Economist. (2013, 18 May). Open data: a new goldmine. Retrieved from www. economist.com/news/business/21578084-making-official-data-public-could-spur-lotsinnovation-new-goldmine.

Torche, F. (2011). Is a college degree still the great equalizer? Intergenerational mobility across levels of schooling in the United States. American Journal of Sociology, $117(3), 763-807$.

Walters, D. (2003). "Recycling": The economic implications of obtaining additional postsecondary credentials at lower or equivalent levels. Canadian Review of Sociology and Anthropology, 40(4), 463-80.

Walters, D. (2004a). The relationship between postsecondary education and skill: Comparing credentialism with human capital theory. Canadian Journal of Higher Education, 34(2), 97-124.

Walters, D. (2004b). A comparison of the labour market outcomes of postsecondary graduates of various levels and fields over a four-cohort period. Canadian Journal of Sociology, 29(1), 1-27. 
Walters, D., \& Frank, K. (2010). Exploring the alignment between postsecondary education programs and labour market outcomes in Ontario. Toronto: Higher Education Quality Council of Ontario.

Zafar, B. (2011). Double majors: One for me, one for the parents? Economic Inquiry, $50(2), 287-308$.

\section{Contact Information}

John Goyder

jgoyder@uwaterloo.ca

University of Waterloo

John Goyder retired as a professor at the University of Waterloo in 2011 and is currently an adjunct professor with the Department of Sociology and Legal Studies at UW. He was president of the Canadian Sociological Association in 2010-2011, and his book The Prestige Squeeze received the John Porter book prize in 2011. 